\title{
DIGITALCOMMONS
}

@WAYNESTATE-

Wayne State University

Human Biology Open Access Pre-Prints

WSU Press

3-30-2020

\section{Indigenizing Science and Reasserting Indigeneity in Research}

Krystal S. Tsosie

Vanderbilt University

Katrina G. Claw

University of Colorado Anschutz Medical Campus

Follow this and additional works at: https://digitalcommons.wayne.edu/humbiol_preprints

\section{Recommended Citation}

Tsosie, Krystal S. and Claw, Katrina G., "Indigenizing Science and Reasserting Indigeneity in Research" (2020). Human Biology Open Access Pre-Prints. 161.

https://digitalcommons.wayne.edu/humbiol_preprints/161

This Article is brought to you for free and open access by the WSU Press at DigitalCommons@WayneState. It has been accepted for inclusion in Human Biology Open Access Pre-Prints by an authorized administrator of DigitalCommons@WayneState. 


\section{Indigenizing Science and Reasserting Indigeneity in Research}

Krystal S. Tsosie1,2 and Katrina G. Claw3,4

1Vanderbilt University, Nashville, Tennessee, USA.

2Department of Science, Technology, Engineering, and Math, Turtle Mountain Community

College, Belcourt, North Dakota, USA.

3Division of Biomedical Informatics and Personalized Medicine, University of Colorado

Anschutz Medical Campus, Aurora, Colorado, USA.

4Colorado Center for Personalized Medicine, University of Colorado Anschutz Medical Campus, Aurora, Colorado, USA.

*Correspondence to: Krystal S. Tsosie, Email: krystal.s.tsosie@gmail.com.

Short Title: Indigenous Science and Research

KEY WORDS: INDIGENOUS, NATIVE AMERICAN, AMERICAN INDIAN, PACIFIC ISLANDER, INDIGENOUS SCIENCE, TRADITIONAL ECOLOGICAL KNOWLEDGE, INDIGENOUS KNOWLEDGE, EPISTEMOLOGIES, COMMUNITY-BASED

PARTICIPATORY RESEARCH, COMMUNITY ENGAGEMENT, RESEARCH FRAMEWORK, GENE DRIVE, STEM EDUCATION. 
Science, at its core, is knowledge systematically gained through repeated observations about the world around us. Indigenous people have always been scientists. As agronomists, Indigenous people of pre-Colombian Mexico domesticated maize over 9,000 years ago (Matsuoka et al. 2002). As astronomers, Polynesians studied constellations and movements of celestial bodies to become skilled sailors and navigators (Lewis 1972). In almost every scientific discipline throughout history, Indigenous people have contributed to our physical and biological understanding and have developed technologies that benefit all. Imagine then how science today could be advanced if we empowered Indigenous approaches to the level of Western science.

Indigenous people have multiple ways of knowing and varied traditional knowledge systems that are distinct from Western perspectives. These epistemologies are embedded in oral traditions, ceremonial practices, beliefs, and general knowledge from our ancestors. Thus, Indigenous science is the process by which Indigenous people construct and disseminate empirical knowledge of their environment. As approaches to gathering knowledge, Indigenous science may arise independently of Western science but the two are not antithetical.

Yet Indigenous science is often overshadowed and minimized by Western science. The latter is often seen by the dominant society as being more "objective" whereas its counterpart might be viewed as anecdotal, imprecise, and valued only by its interoperability with Western perspectives. This veneration of Western science has the effect of undermining the embodied and relational ways of knowing developed over countless generations, passed down by elders to the next generation, and rooted in centuries of observational and experiential learning.

Indigenous science is grounded in traditional knowledge, but it is perhaps the word traditional that seems to cause consternation and derision among non-Indigenous academics. The word itself is often used antonymously with "modern" and therefore implies that such concepts 
are of the past and incompatible with the contemporary world (Pierotti 2012). Perhaps we should instead think of "traditional knowledge" as knowledge that endures, or has been repeatedly tested and remained substantiated. As data points representing countless trials over the course of time, maybe scientists should reevaluate their perceptions of the word traditional and instead acknowledge and listen to expertise in Indigenous science.

Hence, many biologists and conservationists are looking to Traditional Ecological Knowledge (TEK), or Indigenous knowledge (IK) gained through interacting with the environment, to provide solutions to climate change, deforestation, species extinction, and ecosystem degradation-problems arguably implicated by an over-reliance on Western science. For instance, researchers were able to improve their population estimates of bowhead whales in Arctic Alaska by incorporating Iñupiat knowledge of whale behavior (Albert 2001). Elders from the Heiltsuk First Nation in British Columbia long recognized differences between coastal and inland grey wolves in their territory, which informed later genetic investigations comparing the two species (Stronen et al. 2014). As stewards of lands that encompass 22 percent of the Earth's surface including much of its biodiversity (Sobrevila 2008), Indigenous people and IK approaches are perhaps now more important for the planet's sustainability and future.

Looking to Indigenous science to find solutions to systemic issues without concern for the health of Indigenous Knowledge Keepers, however, is extractive. Indigenous people in the United States (US) suffer worse health outcomes and significant barriers to health compared to non-Hispanic whites (Jacobs-Wingo et al. 2016), and these health disparities may be further exacerbated as precision medicine moves forward (Martin et al. 2019) without proper attention to structural barriers to health that overburden these communities (Tsosie et al. 2019). Despite some attention over the years to explore themes of discrimination, racism, historical trauma, and 
cultural concerns interconnected with social determinants and health outcomes (Lafontaine 2018), specific interventional research in Indigenous health is still sorely needed.

It is perhaps time for the greater research community to recognize the voices and views of Indigenous people. Community-engaged approaches (such as community-based participatory research or tribally-driven research) that improve cultural competency of non-Indigenous researchers and elevate Indigenous community members as equal and active research partners in science through the bidirectional exchange of knowledge are becoming more the norm in research (Claw et al. 2018). But there is also a need to encourage and build tribal research capacity so that Indigenous people are empowered to drive positive changes for their own communities. Though the number of US Indigenous scholars awarded doctorate degrees in science fields was less than $0.2 \%$ in 2016 (National Science Foundation and National Center for Science and Engineering Statistics 2019), metrics such as these can be interpreted alternatively. In actuality, more Indigenous researchers are leading traditionally Western academic roles than ever before in spite of the historic lack of diverse voices in academia, thus promoting research that is culturally sustainable and consistent with Indigenous values.

We as Indigenous scientists are proud to be a part of the first special issue devoted to Indigenous Science in an international, peer-reviewed academic research journal devoted to topics in human biology. Our overarching goal for this Human Biology issue is to present and elevate research that incorporates Indigenous approaches and worldviews in the sciences. Syncretizing or integrating Indigenous and Western epistemologies, we hope to demonstrate, adds to foundational knowledge and methods that can advance global understandings of health, medicine, and biology at all intersections. 


\section{Elevating Indigenous Voices in Science}

In October 2019, the co-editors of this special issue organized an invited session at the American Indian Science and Engineering Society (AISES) National Conference in Milwaukee, WI, titled "Indigenizing Science and Reasserting Indigeneity in Research". This special issue of Human Biology features contributions by some of the speakers at this symposium, building on efforts to integrate Indigenous knowledge into the sciences and research.

A core message conveyed at the conference and in this issue is the importance of incorporating Indigenous approaches and epistemological knowledge in the research process, especially when investigating questions related to health and wellness. For instance, the true extent of health disparities underlying personal and community impacts of traumatic spinal cord injuries for First Nations people is poorly understood and largely underrepresented in academic literature. Juutilainen and co-authors see issues stemming from mistrust and inadequacies of applying constructs of Western biomedical care in Indigenous communities. In a departure from more deficit-based narratives of Indigenous health, they offer a strength-based approach that is grounded in Anishinaabe/Cree and Haudenosaunee principles (i.e., the Medicine Wheel and Two Row Wampum, respectively). This could inform culturally-appropriate health care practices for First Nations individuals with debilitating and permanent conditions.

In a similar vein, we see Elm and Handeland unpack the processes by which researchers develop culturally-congruent interventions through meaningful tribal involvement and ethical community-oriented approaches using the Gathering for Health Project, an ongoing study to understand the physical, mental, and social health impacts of type II diabetes for tribal members of Great Lakes region. They deconstruct the major themes that drive momentum and facilitate longevity of successful community-based approaches_-such as Indigenous scholar involvement, 
time and effort, communication, establishing rapport, as well as generative co-learning, active participation, and recognition and celebration - that may hopefully provide a template for future researchers hoping to engage Indigenous communities.

Language, or how we disseminate and describe ideas, appears to be an important theme echoed by many articles in this issue. As future research increasingly relies on data and computational methods across multiple disciplines, Duarte et al. argue that IK, TEK, and other Indigenous expressions of relationality could enrich our understanding of systems-based approaches. Rather than treating each datum separately, adopting a more holistic understanding of patterns and trends across research domains could reveal more network-based connections that, in actuality, are more aligned with Indigenous constructs of interconnectedness, and could produce new conceptual frameworks and methodologies within an Indigenous context.

Of course, discourse about advancing science in Indigenous communities must always acknowledge the research conducted in the past. Taitingfong argues that the language surrounding the genetic engineering technology called gene drive is clouded in settler colonialism terms that recall a painful history of military experimentation on Indigenous lands and peoples. In drawing parallels with the Cold War era nuclear testing that treated Pacific islands as "ideal" test sites, Taitingfong astutely reminds that science can be a vehicle of perpetrating injustice and that the exclusion of key Indigenous stakeholders in the research process is tantamount to repeating ethical mistakes of history. This continued blunder would be especially egregious as the field of genetics continues to progress technologically and aims to include more diverse groups in research.

As an interesting approach to operationalize the extent of genetics research in a tribal context, Begay et al. conducted an in-depth literature review of genetics research involving Diné 
(Navajo) people over the course of 93 years. In addition to providing commentary on trends in genetics, the co-authors also chronicle changes in these fields pre- and post- benchmark years in the Navajo Nation's history of self-determining research regulations for their peoplespecifically the institution of the Navajo Nation Human Research Review Board and their moratorium on genetics research. A nuanced reading of Begay et al. will reveal that a vast majority of studies included in their review are contributed by the Native Health Database, a manual curation by an Indigenous researcher, which highlights the missingness of historical knowledge when we rely solely on PubMed, MEDLINE, or similar archives. Again, we reiterate the importance of utilizing Indigenous resources and sources to inform research and to reduce the bias of outside non-Indigenous researchers' perspectives. While the article keenly contextualizes genetics with Diné cultural practices and worldviews related to $k$ 'e' (system of clans and relationality) and sheep breeding, the underlying message is deeply more profound: Indigenous people have always been geneticists.

At the outset, our aim was to assert Indigenous science as a valid approach. Our product is an issue that is entirely Indigenous-driven. Our authors represent a range in Indigenous voices and perspectives that are reflective of the vast cultural diversity of Indigenous people, who are all promoting change in various fields of human biology and health. Every stage of the peer-review process in this issue was guided by Indigenous researchers - from the authors, editors, and our wonderful reviewers. This will be the first of many issues to come, especially as additional journals recognize the importance of making space for Indigenous voices in research (Nature Genetics 2020). In an era that will welcome new Indigenous researchers into the academic and research space, we hope to continue an Indigenous science tradition that is driven by us, for us. 
Received 19 March 2020; accepted for publication 19 March 2020.

Pre-print version. Visit http://digitalcommons.wayne.edu/humbiol/ after publication to acquire the final version. 


\section{Literature Cited}

Albert, T. F. 2001. The influence of Harry Brower, Sr., an Iñupiaq Eskimo hunter, on the Bowhead Whale Research Program conducted at the UIC-NARL Facility by the North Slope Borough. In Fifty More Years Below Zero: Tributes and Meditations for the Naval Arctic Research Laboratory's First Half Century at Barrow, Alaska, D. W. Norton, ed. Calgary, AB: Arctic Institute of North America; Fairbanks, AK: University of Alaska Press, 265-278.

Begay, R. L., Garrison, N. A., F. Sage et al. 2020. Weaving the strands of life (Iiná Bitł'ool): History of genetic research involving Navajo people. Hum Biol.

Claw, K. G., M. Z. Anderson, R. L. Begay et al. 2018. A framework for enhancing ethical genomic research with indigenous communities. Nat. Commun. 9:1-7.

Duarte, M. E., M. Vigil-Hayes, S. Littletree et al. 2020. 'Of course, data can never fully represent reality': Assessing the relationship between Indigenous data and IK, TEK, and TK. Hum Biol.

Elm, J., and T. Handeland. 2020. Momentum and longevity for tribally-driven health equity science: Evidence from the Gathering for Health Project. Hum Biol.

Jacobs-Wingo, J. L., D. K. Espey, A. V. Groom et al. 2016. Causes and disparities in death rates among urban American Indian and Alaska Native populations, 1999-2009. Am. J. Public Health 106:906-914.

Juutilainen, S. A., M. Jeffrey, and S. Stewart. 2020. Methodology matters: Designing a pilot study guided by Indigenous epistemologies. Hum Biol.

Lafontaine, A. 2018. Indigenous health disparities: A challenge and an opportunity. Can. J. Surg. 61:300-301. 
Lewis, D. 1972. We, the Navigators: The Ancient Art of Landfinding in the Pacific, D. Oulton, ed. Honolulu, HI: University of Hawai'i Press.

Martin, A. R., M. Kanai, Y. Kamatani et al. 2019. Clinical use of current polygenic risk scores may exacerbate health disparities. Nat. Genet. 51:584-591.

Matsuoka, Y., Y. Vigouroux, M. M. Goodman et al. 2002. A single domestication for maize shown by multilocus microsatellite genotyping. Proc. Natl. Acad. Sci. U. S. A. 99:6,0806,084 .

National Science Foundation, National Center for Science and Engineering Statistics. 2019. Women, Minorities, and Persons with Disabilities in Science and Engineering. Special Report NSF 19-304. Alexandria, VA: NSF and NCSES.

Nature Genetics. 2020. Necessary voices. Nat. Genet. 52:135.

Pierotti, R. 2012. Indigenous Knowledge, Ecology, and Evolutionary Biology. New York: Routledge.

Sobrevila, C. 2008. The Role of Indigenous Peoples in Biodiversity Conservation: The Natural but often Forgotten Partners. Washington, D.C.: The World Bank.

Stronen, A. V., E. L. Navid, M. S. Quinn et al. 2014. Population genetic structure of gray wolves (Canis lupus) in a marine archipelago suggests island-mainland differentiation consistent with dietary niche. BMC Ecol. 14:1-9.

Taitingfong, R. I. 2020. Islands as laboratories: Indigenous knowledge and gene drives in the Pacific. Hum Biol.

Tsosie, K. S., J. M. Yracheta, and D. Dickenson. 2019. Overvaluing individual consent ignores risks to tribal participants. Nat. Rev. Genet. 20:497-498. 